Bangladesh J. Zool. 49 (2): 277-288, 2021

ISSN: 0304-9027

eISSN: $2408-8455$

\title{
MARKET SURVEY OF FRESH AND MARINE WATER FISHES AND SOCIOECONOMIC CONDITIONS OF FISH RETAILERS IN THREE MARKETS OF CHATTAGRAM CITY
}

\author{
Dil Afroja Sultana, Munira Nasruddin*, M.A. Azadi and \\ Mosammat Rasheda Chowdhury \\ Department of Zoology, University of Chittagong, Chattagram 4331, Bangladesh
}

\begin{abstract}
The study was carried out to survey the fresh and marine water fishes sold out in three markets of Chattagram city and socioeconomic condition of the fish retailers. Overall 29 fresh water and 24 marine water fish species were found to be sold in the three markets. Prices of fishes were higher in Kazirdewri Bazar followed by Riazuddin Bazar and Bohaddarhat Bazar. Data of fish retailers were collected through questionnaires in terms of age, income source, living standards, family size, financial facilities, literacy and education. Sole income came from fish business for $97 \%$ of the fish retailers, whilst $3 \%$ of the retailers did other business as well. Among 45 retailers interviewed, $40 \%$ were below 45 years, 53\% were between $45-55$ years and remaining $7 \%$ were above 55 years age. For coping with the business, $15 \%$ of the retailers were self-sufficient, $53 \%$ took loan from bank, whilst $32 \%$ took loan from local money lenders. Of the fish retailers, $34 \%$ was illiterate and $66 \%$ was literate, where $36 \%$ received up to primary level, $16 \%$ secondary level, $10 \%$ S.S.C and 4\% H.S.C levels of education. In comparison with their education status their children were more educated (93\%). Although their income was low, they tried to make their children educated, which is a good sign for our education sector. Transport cost, unhygienic market place, lack of sanitary facilities, poor ice-supply, exploitation by the middlemen, lack of proper management, lack of capital and the political disturbances were the common constraints of fish marketing. Necessary measures were recommended to overcome these problems.
\end{abstract}

Key words: Market survey, freshwater fish, marine water fish, socioeconomic condition, fish retailers.

\section{INTRODUCTION}

Marketing is the connecting link between the producers and consumers. An effective marketing system is necessary to make products, being available to consumers at the right time and in the right place. There are many constraints in fish marketing such as lack of modern fish landing center and retail markets

*Author for corresponding: <muniranasiruddin@yahoo.com>

(1)2021 Zoological Society of Bangladesh DOI: https://doi.org/10.3329/bjz.v49i2.56264 
near the fish landing port, introduction of government fish shops and insulated and refrigerated fish vans and fish carriers, training of all personnel related to fish marketing and about fish handling, quality of fish, hygiene practices, improvement of existing fish market structure, provision for government and private funding assistance for fishers/fish farmers, formulation and enactment of independent act/ordinance for fish landing and marketing (Rahman et al., 2015). The fish market in our country is virtually within a cluster of disorganized activities and always remains in the control of influential persons of the surrounding areas, depending on a wide range of social, economic and political factors (Nayeem et al., 2010).

Importance of fish markets in Bangladesh, in terms of value and employment is enormous. Fish marketing systems are traditional, complex and less competitive, but is said to play a vital role in connecting the fisherman and fish consumers. Domestic fish markets of Bangladesh can be divided into two types i.e. wholesale and retail markets. Wholesale markets should have facilities for carrier vehicle parking, space for loading/unloading, ice plants, wash rooms etc. Retail markets are often crowded places, mostly on pavements or within closed boundaries with poor hygienic condition. Two main categories of fish retailers have been encountered- market based retailers and retailers like fish vendors and haulers. Retail sells are made at stalls in fish markets and door to door to household customers. In the fish marketing system, the auctioneers and suppliers play a crucial role in determining price for fishes.

The socioeconomic aspect illustrates the status, income-expenditure, housing, standard of living, literacy, occupation, health and sanitation, hygiene, food and nutrition, education and economic conditions of the people (Hossain et al., 2015). For planning, decision making, developing and implementation in fisheries sector and fisher's community, it is necessary to gather knowledge regarding the fish marketing system and socioeconomic condition of related people such as the fish retailers. Related works in this aspect are those of Zaman et al. (2006), Sultana and Thompson (2007), Ali et al. (2008), Asaduzzaman et al. (2010), Aktar et al. (2010), Ali et al. (2014), Sharif et al. (2015), Asif and Habib (2017) and Ali et al. (2017).

A study of the fish marketing and socioeconomic study of fishing community is a pre-requisite for the good design and successful implementation of effective programs. Considering the financial hardship and other complexities of the fish retailers, it is important to analyze their livelihood status. In view of these considerations, the main objectives of the present study are: 
- To make a market survey of the available fishes in the three renowned markets i.e. Kazirdewri Bazar, Riazuddin Bazar and Bohoddarhat Bazar of Chattagram city with a comparison of price values of the fishes.

- To assess the socioeconomic conditions of some fish retailers of the three markets, with constraints to and potentials and opportunities, as a background, to a more in-depth analysis later.

\section{MATERIAL AND METHODS}

Study area: The bulk of the survey work for this study took place for a period of six months between February 2014 and July 2014 from the three renowned

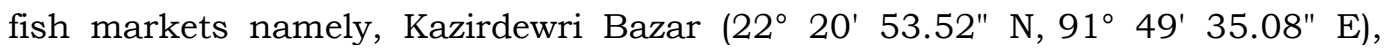

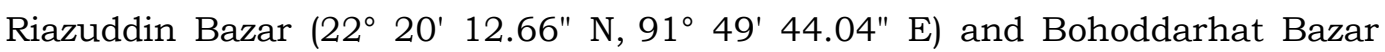
$\left(22^{\circ} 22^{\prime} 6.42^{\prime \prime} \mathrm{N}, 91^{\circ} 50^{\prime} 34.19^{\prime \prime} \mathrm{E}\right)$ of Chattagram city. The study was based firstly upon survey of fishes and their market price and secondly, the socioeconomic conditions of some of the fish retailers, surveyed with the help of set of questionnaires.

Data collection: The data and information had been collected from both primary and secondary sources. Collection of field data was done fortnightly and was conducted using two methods (structured interview and focus group discussion) (Hasan et al., 2018). Primary data had been collected by interviewing through questionnaires with the fish retailers and secondary sources related information from internet. A total of 45 fish retailers, selected randomly (15 from each market) were interviewed and their responses were recorded in the preset questionnaires. Questionnaire surveys were used to get the idea of availability of different fish species and in different markets along with their monthly selling price and socioeconomic condition of the fish retailers. This technique was implemented because most of the fish retailers were uneducated or had a low level of education (Shamsuddoha, 2007).

Identification of the fishes was done following Quddus and Shafi (1995), Talwar and Jhingran (2001), Rahman (2005) and internet source (Fishbase).

\section{RESULTS AND DISCUSSION}

Market survey: During the six months of study period, a atotal of 29 freshwater fish species and a total of 24 marine water fish species were found in all of the three fish markets. For the freshwater fishes, almost all the fishes were available in all the three markets except Pygocentrus natteri and Hyporhampus limbatus in Kazirdewri Bazar; Pygocentrus natteri, Xenetodon cancila, Channa striatus, Securicula gora, Wallago attu and Sperata aor in Riazuddin Bazar and 
Table 1. Mean price values \pm SE (Taka per $\mathrm{kg}$ ) of freshwater fishes in the three studied fish markets

\begin{tabular}{|c|c|c|c|c|}
\hline Local name & Scientific name & $\begin{array}{c}\text { Kazirdewri } \\
\text { Bazar } \\
\text { (Taka per kg) }\end{array}$ & $\begin{array}{c}\text { Riazuddin } \\
\text { Bazar } \\
\text { (Taka per kg) }\end{array}$ & $\begin{array}{c}\text { Bohoddarhat } \\
\text { Bazar } \\
\text { (Taka per kg) }\end{array}$ \\
\hline Silver carp* & Hypopthalmichthys molitrix & $228.33 \pm 10.14$ & $185.00 \pm 7.19$ & $163.33 \pm 9.19$ \\
\hline Common carp* & Cyprinus carpio & $216.67 \pm 11.74$ & $180.00 \pm 5.16$ & $150.00 \pm 8.56$ \\
\hline Tilapia* & Oreochromis niloticus & $193.33 \pm 6.67$ & $155.00 \pm 5.63$ & $166.67 \pm 13.08$ \\
\hline Meni & Nandus nandus & $423.33 \pm 9.19$ & $380.00 \pm 10.00$ & - \\
\hline Red Piranha* & Pygocentrus natteri & - & - & $105.00 \pm 4.99$ \\
\hline Kakila & Xenentodon cancila & $213.33 \pm 21.86$ & - & $193.33 \pm 4.22$ \\
\hline Ekthota & Hyporhampus limbatus & - & $280.00 \pm 10.00$ & $250.00 \pm 6.83$ \\
\hline Shol & Channa striatus & $380.00 \pm 10.00$ & - & $321.67 \pm 13.02$ \\
\hline Taki & Channa punctatus & $250.00 \pm 15.06$ & $188.33 \pm 19.05$ & $143.33 \pm 4.22$ \\
\hline Ghora chela & Securicula gora & $370.00 \pm 10.95$ & - & - \\
\hline Kalibaus & Labeo calbasu & $480.00 \pm 10.00$ & $438.33 \pm 31.14$ & $305.00 \pm 16.07$ \\
\hline Rui & Labeo rohita & $371.67 \pm 10.14$ & $200.00 \pm 7.30$ & $196.67 \pm 6.15$ \\
\hline Mrigal & Cirrhinus cirrhosis & $198.33 \pm 4.77$ & $180.00 \pm 7.30$ & $150.00 \pm 11.25$ \\
\hline Sarpunti & Barbodes sarana & $320.00 \pm 10.00$ & $358.33 \pm 20.07$ & $268.33 \pm 11.67$ \\
\hline Catla & Catla catla & $375.00 \pm 21.41$ & $270.00 \pm 10.33$ & $151.67 \pm 3.07$ \\
\hline Magur & Clarias batrachus & $830.00 \pm 18.26$ & $733.33 \pm 40.14$ & $700.00 \pm 12.91$ \\
\hline Pabda & Ompok pabda & $775.00 \pm 47.87$ & $591.67 \pm 59.74$ & - \\
\hline Boal & Wallago attu & $680.00 \pm 10.00$ & - & $618.33 \pm 17.40$ \\
\hline Shingi & Heteropneustes fossilis & $875.00 \pm 30.96$ & $800.00 \pm 28.87$ & $866.67 \pm 16.67$ \\
\hline Pangus & Pangasius pangasius & $166.67 \pm 8.43$ & $153.33 \pm 9.55$ & $138.33 \pm 6.01$ \\
\hline Ayre & Sperata aor & $858.33 \pm 15.36$ & - & - \\
\hline Foli & Notopterus notopterus & $371.67 \pm 10.14$ & $285.00 \pm 8.06$ & $250.00 \pm 6.83$ \\
\hline Tara baim & Macrognathus aculeatus & $380.0 \pm 7.75$ & $376.67 \pm 9.19$ & - \\
\hline Koi & Anabas testudineus & $758.33 \pm 20.07$ & $575.00 \pm 38.19$ & $385.00 \pm 8.06$ \\
\hline Mola & Amblypharyngodon mola & $198.33 \pm 6.01$ & $263.33 \pm 7.60$ & $245.00 \pm 9.22$ \\
\hline Rita & Rita rita & - & - & $228.33 \pm 7.49$ \\
\hline Bajaritengra & Mystus tengara & $430.00 \pm 10.00$ & $325.00 \pm 11.18$ & $326.67 \pm 8.03$ \\
\hline Chiring & Apocryptes bato & $413.33 \pm 12.02$ & $261.67 \pm 15.15$ & - \\
\hline Prawn & Macrobrachium rosenbergii & $1116.67 \pm 47.43$ & $841.67 \pm 23.86$ & $858.33 \pm 20.07$ \\
\hline
\end{tabular}

${ }^{*}$ Exotic fish

Nandus nandus, Securicula gora, Ompok pabda, Sperata aor, Macrognathus aculeatusand Apocryptes bato in Bohoddarhat Bazar.

In all the three markets, for the marine water fishes, it was observed that almost all the fishes were available in all the three markets except Pomadasys hasta and Lepturacanthus savala in Kazirdewri Bazar; Colia dussumieri, Corica soborna, Ilisha megaloptera, Rhinomugil corsula, Epinephelus megachir and Lepturacanthus savala in Riazuddin Bazar; and Colia dussumieri, Pampus argenteus, Rhinomugil corsula, Platycephalus indicus, Silaginopsis panigus, Argyrops spinifer and Epinephelus megachir in Bohaddarhat Bazar. Of the freshwater fishes that were exclusively available in Kazirdewri Bazar were Securicula gora and Sperata aor and that available in Bohoddarhat Bazar was Pygocentrus natteri and Rita rita. Amongst the marine water fishes which were solely available in Kazirdewri Bazar were Colia dussumieri, Rhinomugil corsula 
and Epinephelus megachir, whilst that available in Bohoddarhat Bazar was Lepturacanthus savala only.

In abundance, Kazirdewri Bazar was rich in both freshwater (26 species) and marine water fish (22 species), and Riazuddin Bazar with 22 fresh water and 19 marine water and Bohoddarhat Bazar with 23 fresh water and 17 marine water species were comparatively less abundant with fish. Most of the fishes were common to all the three fish markets. One species of marine water fish, Khorsula (Rhinomugil corsula) which is both marine as well as freshwater and Bol koral (Epinephelus megachir) were exclusively found in Kazirdewri Bazar which are rare species to Bangladesh.

The price values of the available fish species, both fresh and marine water, in the three markets are given in Tables 1 and 2. The price of fishes, both fresh and marine water, among the three studied markets, were highest in Kazirdewri Bazar due to its location in the center of the city and as well as being besides a well to do residential area. A comparatively lesser fish price was seen in Riazuddin Bazar, which is also a very well known fish market, whereby most of the fishes are collected from fishery ghat. Whereas, in Bohoddarhat Bazar fish prices were observed to be the lowest, which might be due to low cost in transportation of fishes and being a busy commercial area.

Socioeconomic condition of the fish retailers: The socioeconomic condition of fish retailers of the three fish markets surveyed on the following aspects is described. A total of 45 fish retailers were interviewed through preset questionnaire from the three markets.

Accommodation facilities: Accommodation facilities depended on well beeing of the fish retailers. In the three study areas, the fish retailers used to live in three types of houses such as, semi pacca, pacca and thatched houses. Of them, $49 \%$ lived in semi pacca, $22 \%$ lived in pacca houses and rest $29 \%$ of the fish retailers lived in thatched houses (Fig. 1a). Similar observation was also reported by Sharif et al. (2015) where they found the fish retailers to live in three types of houses i.e. earthen, semi-pacca and pacca.

Age distribution of fish retailers: Age indicates at which stage of their life they are engaged in the job. In the three study areas, most of the fish retailers were of age of above 45 years. The percentage of age distribution was as such, $40 \%$ of the retailers were below 45 years- the age of prime activity for human beings, 53\% traders were $45-55$ years of age- an active age category and $7 \%$ of the respondents were above 55 years (Fig. 1b). Asif and Habib (2017), Hossain et al. (2015) and Sharif et al. (2015) had also categorized them into three age groups, whereas Asaduzzaman et al. (2010) categorized them into four age groups. For most of the retailers, the occupation was whereas inherited, whereas for others it was a new occupation. 
Table 2. Mean price values \pm SE (Taka per $\mathrm{kg}$ ) of marine fishes in the three studied fish markets

\begin{tabular}{|c|c|c|c|c|}
\hline Local name & Scientific name & $\begin{array}{c}\text { Kazirdewri } \\
\text { Bazar } \\
\text { (Taka per kg) }\end{array}$ & $\begin{array}{c}\text { Riazuddin } \\
\text { Bazar } \\
\text { (Taka per kg) }\end{array}$ & $\begin{array}{l}\text { Bohoddarhat } \\
\text { Bazar } \\
\text { (Taka per kg) }\end{array}$ \\
\hline Loitta & Harpodon nehereus & $181.67 \pm 6.54$ & $110.00 \pm 10.95$ & $93.33 \pm 2.11$ \\
\hline Olua & Colia dussumieri & $2633.30 \pm 8.43$ & - & - \\
\hline Ilish* & Tenualosa ilisha & $791.67 \pm 37.45$ & $645.00 \pm 32.53$ & $658.33 \pm 20.07$ \\
\hline Kachki* $^{*}$ & Corica soborna & $226.67 \pm 9.54$ & - & $233.33 \pm 4.22$ \\
\hline Choukka & Ilisha megaloptera & $360.00 \pm 14.37$ & - & $266.67 \pm 9.55$ \\
\hline Kalochanda & Parastromateus niger & $400.00 \pm 12.91$ & $313.33 \pm 12.02$ & $265.00 \pm 6.71$ \\
\hline Rup chanda & Pampus chinensis & $805.00 \pm 16.07$ & $816.67 \pm 21.08$ & $800.00 \pm 12.91$ \\
\hline Folichanda & Pampus argenteus & $400.00 \pm 18.26$ & $320.00 \pm 10.00$ & - \\
\hline Taposi & Polynemus paradiseus & $191.67 \pm 4.01$ & $150.00 \pm 15.05$ & $146.67 \pm 2.11$ \\
\hline Tailla & $\begin{array}{l}\text { Eleutheronematetra } \\
\text { dactylum }\end{array}$ & $433.33 \pm 13.08$ & $340.00 \pm 6.32$ & $235.00 \pm 5.63$ \\
\hline Khorsula* & Rhinomugil corsula & $466.67 \pm 16.67$ & - & - \\
\hline Bata* & Mugil cephalus & $450.00 \pm 18.26$ & $310.00 \pm 13.17$ & $240.00 \pm 6.32$ \\
\hline Mur baila & Platycephalus indicus & $433.33 \pm 8.43$ & $460.00 \pm 15.28$ & - \\
\hline Tulardandi & Silaginopsis panijus & $313.33 \pm 12.01$ & $193.33 \pm 4.22$ & - \\
\hline Poa* & Otolithoides pama & $311.67 \pm 15.36$ & $238.33 \pm 9.80$ & $200.00 \pm 4.47$ \\
\hline Guti poa & Pterotolithus maculatus & $423.33 \pm 9.19$ & $336.67 \pm 8.82$ & $331.67 \pm 8.72$ \\
\hline Koitor poa* & Johnius coitor & $266.67 \pm 16.67$ & $211.67 \pm 9.80$ & $293.33 \pm 4.22$ \\
\hline Bhetki* & Latesc alcarifer & $625.00 \pm 38.19$ & $455.00 \pm 16.07$ & $385.00 \pm 8.06$ \\
\hline Shurma & Rastrelliger kanagurta & $386.67 \pm 16.26$ & $328.33 \pm 10.14$ & $228.33 \pm 10.14$ \\
\hline Koi coral & Lobotes surinamensis & $441.67 \pm 15.36$ & $441.67 \pm 32.70$ & $290.00 \pm 4.47$ \\
\hline Datina coral & Pomadasys hasta & - & $525.00 \pm 38.19$ & $293.33 \pm 4.22$ \\
\hline Lal coral & Argyrops spinifer & $345.00 \pm 18.93$ & $373.33 \pm 8.03$ & - \\
\hline Bol coral & Epinephelus megachir & $423.33 \pm 9.19$ & - & - \\
\hline Churi & Lepturacanthus savala & - & - & $196.67 \pm 6.15$ \\
\hline
\end{tabular}

*As well as freshwater

Family size and living condition: The study of family size i.e. number of people per family is of great importance and has a great impact on the maintenance and economic condition of the family as well as their social status. Families may be considered in three groups according to their size, viz. small families with 2-4 members, medium families with 5-7 members and large families with 8-10 members or more. Amongst the fish retailers, $13 \%$ had large 
families, $47 \%$ had medium families and $40 \%$ had small families (Fig. 1c). Hossain et al. (2015) also grouped family size into three categories, whereas Asif and Habib (2017) categorized it into four groups. Obviously living condition of small sized families was best, whilst the large sized families struggled hard for living.

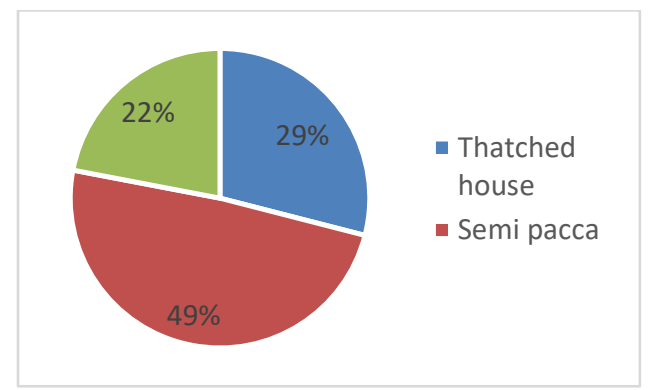

(a) Accommodation facilities

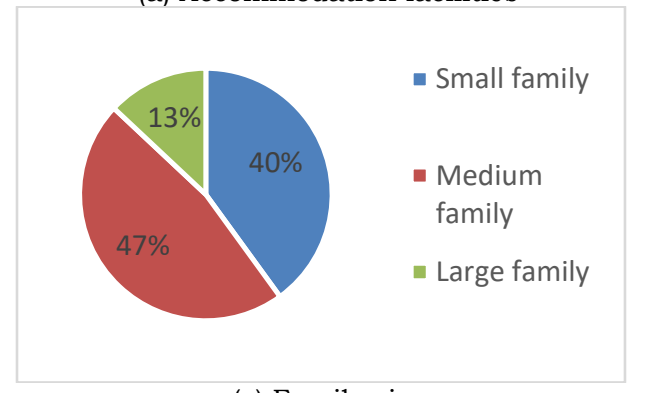

(c) Family size

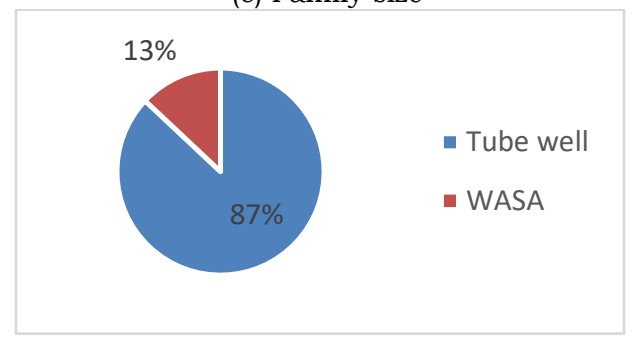

(e) Drinking water facilities

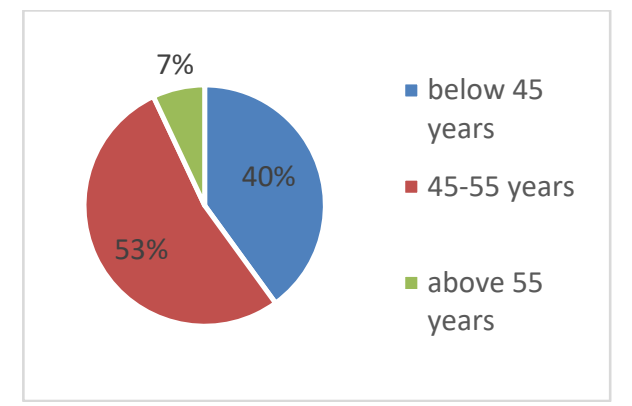

(b) Age distribution

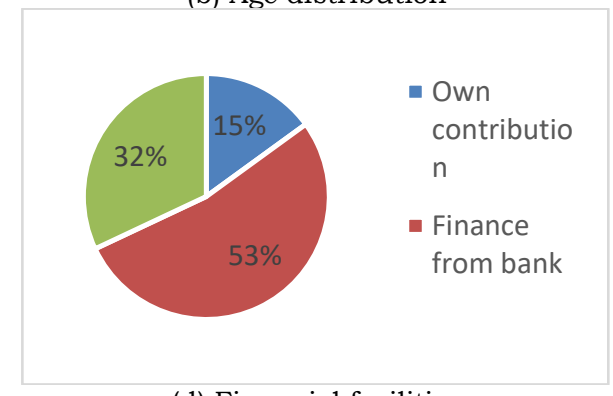

(d) Financial facilities

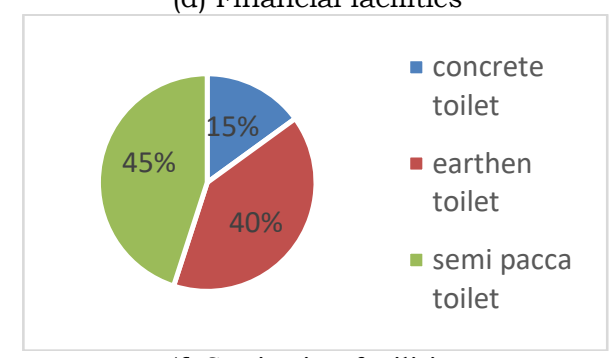

(f) Sanitation facilities

Fig.1. (a) Accommodation facilities, (b) Age distribution, (c), Family size, (d) Financial facilities, (e) Drinking water facilities, and (f) Sanitation facilities of the fish retailers.

Financial facilities and gains: Most of the retailers involved in fish trading were poor and their financial facilities were not so good. In the three study areas, it was observed that $15 \%$ of credits were contributed by the retailers themselves, $53 \%$ retailers got finance from bank, whereas $32 \%$ retailers took loan from local money lenders with a high rate of interest (Fig. 1d). Sharif et al. 
(2015) also reported same sources of financial support for fish retailers. At the end of the day, financial gains indicated their well beeing.

Drinking water facilities: As most of the fish retailers were poor and lived in low cost houses, so, they did not get not much facilities for getting pure drinking water. In the study areas, the retailers were mainly dependent on tubewell water for drinking purposes. In the present study, $87 \%$ of the fish retailers used

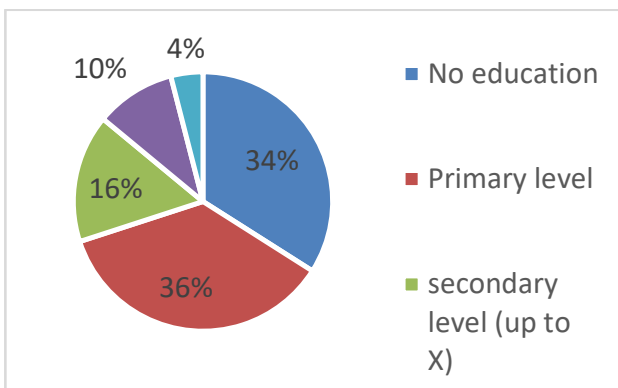

(a) Educational status

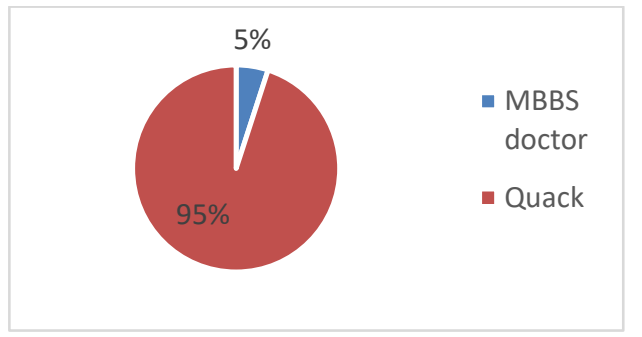

(c) Medical facilities

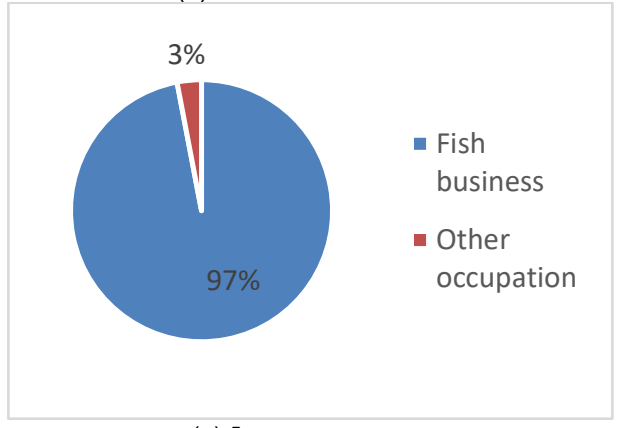

(e) Income source

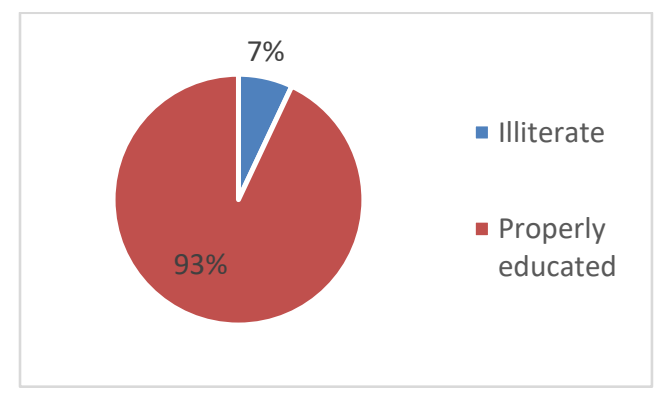

(b) Children education level

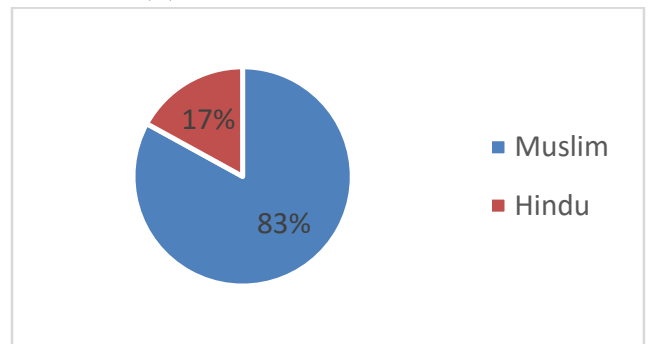

(d) Religious status

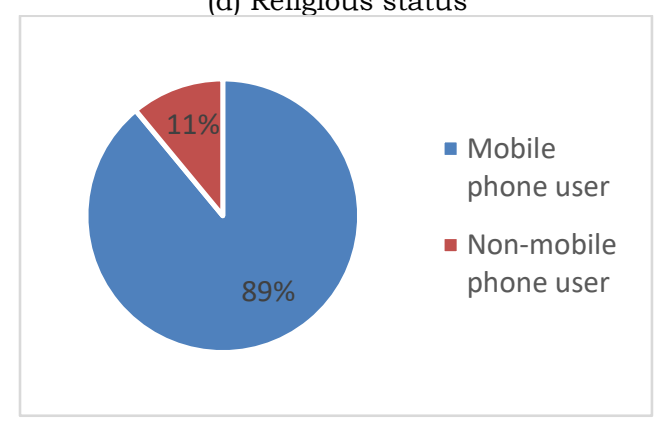

(f) Phone user

Fig.2. (a) Educational status, (b) Children education level, (c) Medical facilities, (d) Religious status, (e) Income source, and (f) Phone user of the fish retailers.

tubewell water and rest $13 \%$ used water supplied by Chattagram WASA for drinking (Fig. 1e). However, Sharif et al. (2015) reported two sources (tubewell and pond) of drinking water. 
Sanitation facilities: Sanitation facilities are prime requisite of human beings for maintaining hygiene. The sanitation facilities used by the fish retailers were of three types of toilets i.e. concrete toilet, earthen toilet and semi-pacca toilet. It was found that $15 \%$ of the fish retailers used concrete toilet, $40 \%$ of the retailers used earthen toilet and $45 \%$ of them used semi-pacca toilet (Fig. 1f). Similar finding on sanitation was also reported by Sharif et al. (2015).

Educational status of fish retailers: Four categories were used to determine the level of education of fish retailers i.e. illiterate, literate up to primary level, up to secondary level and above secondary level. Out of 45 fish retailers, 34\% had no education (illiterate), 36\% had primary level, $16 \%$ had secondary level (up to X), 10\% had S.S.C level, 04\% received up to H.S.C level of education (Fig. 2a). Four education groups were also reported by Hossain et al. (2015). However, Sharif et al. (2015) grouped them into two categories only (literate and illiterate), Asaduzzaman et al. (2010) grouped them into five education groups and Asif and Habib (2017) grouped the retailers into six education categories.

Level of education of the fish retailers' children: Education is an important factor in changing attitudes, motivation and status of a person. Only $7 \%$ of the children of the fish retailers were illiterate due to poverty and had to join their parent for earning livelihood, whereas, the rest 93\% had received proper education, from S.S.C. to degree level (Fig. 2b). So, it can be said that, education among majority of fish retailers' children had been given emphasis, although they themselves were not educated enough. Under literacy Asif and Habib (2017) categorized the education of their children into four group i.e. primary, secondary, higher-secondary and bachelor.

Medical facilities: In the three study areas, among the fish retailers, in case of illness, $95 \%$ of the retailers and their family members were served by quack doctors for treatment because of financial crisis and only $5 \%$ of the retailers took medication from qualified doctors (Fig. 2c). In case of major illness they go to the Chittagong Medical College hospital for treatment. Similarly Sharif et al. (2015) reported two sources from where fish retailers got medical facilities, whereas, Hossain et al. (2015) reported four sources of medical facilities obtained by them.

Religious status: Both Hindus and Muslims were involved in fish trading in the three study areas. Among 45 fish retailers, $83 \%$ were Muslim and rest $17 \%$ were Hindu indicating that Muslim caste was the dominating group (Fig. 2d). All the cited literatures reported two above mentioned religious groups except Sharif et al. (2015), whereby they reported only 100\% Muslim fish farmers in their study area. 
Income sources: Most of the fish retailers depended on fish business and their income came mainly from this business only. For $97 \%$ of the fish retailers, total income came from fish business and 3\% were involved in other occupations as well such as secondary business like vegetable business, agricultural activity, and motorized vehicle operation etc. (Fig. 2e). However, besides fish business, Asif and Habib (2017) and Hossain et al. (2015) reported four other occupations of fish traders in their studies.

Phone users: In the three study areas most of the fish retailers used mobile phone. It was observed that $89 \%$ of the fish retailers used mobile phone and only $11 \%$ were poor enough and could not afford to buy mobile phone for communication (Fig. 2f). None of the fish retailers could access to or operate internet. Asif and Habib (2017) in their study reported $100 \%$ mobile users but they did not give any information about usage of internet by fish retailers.

The nature of the occupation pursued by a person determines to a great extent one's status in the community. Closely related with this is the issue of income, as ones income has much to do with one's social status. Education deeply influences individual preferences and behavioral tendencies. In an analysis of socioeconomic characteristics of a community, the study of housing condition and land holdings has also of great significance. In these connections, occupation, income, literacy and education and earner dependency of fisheries associates such as the fish retailers may be brought under focus. Constraints observed in marketing were mainly transport cost, unhygienic market place, lack of sanitary facilities, poor ice supply, exploitation by middleman, lack of proper management, lack of capital and political disturbances. It is presumed that all of the fish retailers were suffering from social conflict and tension as to live in a good society with good environment. Problems encountered in the business included factors as- absence of government control and participation, absence of proper management committee, relatively less buyers, poor parking condition, drainage system and overall improvement of market committee.

\section{CONCLUSION}

From the findings of the present study, it can be concluded that proper fish market is necessary for the successful management of fish. Fish are marketed here in fresh and iced condition. But the existing drawbacks of the market in terms of environment and intermediaries system make the fish market challenging. Proper management of the fish market need strict monitoring by both government and the private sectors. From the study following recommendations can be made to improve the market condition: 
- Fish retailers should form a co-operative society.

- Need easy loan for financial support.

- Hygienic environment should be ensured.

- Drinking and sanitation system must be available.

- The government should monitor the market on a regular basis.

- The government should give transportation facilities and great infrastructural facilities.

This study discovered the problems and potentials of the three major fish markets of Chattagaram city (Kazirdewari Bazar, Riazuddin Bazar and Bohoddarhat Bazar) that can be beneficial for the policy maker, future researchers as well as the government. This study will help the researchers to uncover the critical areas of above mentioned three fish markets that the researchers were not able to explore. At the same time, the socio-economic condition of fish retailers should also be standardized as they are a major part of our society and also play an important role in the country's "Blue economy".

\section{LITERATURE CITED}

AKTAR, N., BASHAR, M. A., ISLAM, M. T., BARMAN, A. C. and TEHJIB, M. S. 2010. Fish marketing system and socioeconomic status of fish retailers in three markets of Puthia upazila, Rajshahi district. Bangladesh J. Agrofor. Environ. 3(2): 223-226.

ALI, M. H., HOSSAIN, M. D., HASAN, A. N. G. M. and BASHAR, M. A. 2008. Assessment of the livelihood status of the fish farmers in some selected areas of Bagamara upazila under Rajshahi district. J. of Bangladesh Agric. Univ. 6(2): 367-374.

ALI, M. M., RAHMAN, M. M., HOSSAIN, M. Y., RAHMAN, M. Z., HOSSAIN, M. A., NASER, S. M. A., ISLAM, R., SUBBA, B. R., MASUD, Z. and HOQUE, M. A. 2014. Fish marketing system in Southern Bangladesh: Recommendations for efficient marketing. Our Nature 12(1): 28-36. https://doi.org/10.3126/on.v12i1.12254

ALI, M. Y., SHAHARIOR, H., AZAD, S. M. O., SHAHIN, M. A., MONDAL, M. A. H., ALI, M. M. and HOSSAIN, M. B. 2017.Fish availability and marketing system at local markets of a coastal district, southern Bangladesh.Asian Journal of Animal Sciences 11: 221-229.

ASADUZZAMAN, A., TAYEBI, K. A., ALAM, M. M., ALI, M. S. and BARMAN, A. C. 2010.

Marketing system of fishes and socioeconomic condition of fish retailers in Rajshahi city Corporation. Bangladesh J. Agrofor. Environ. 3 (2): 207-211.

ASIF, A. A. and HABIB, M. A. B. 2017. Socioeconomic condition of fish farmers of Jhikargachha upazila in Jessore district, Bangladesh. Asian J. Med. Biol. Res. 3(4): 462-475.

HASAN, A. K. M. S., HOSSAIN, M. E., BHUYAN, M. S., SARKAR, M. S. I., BILLAH, M. M. and CHAWDHURY, D. 2018. Constraints and potentials of fish markets in Chittagong city: A case study of Kazir Dewari Bazar. Journal of Applied Sciences 18: 138145.DOI: $10.3923 /$ jas.2018.138.145 
HOSSAIN, F. I., MIAH, M. I., HOSEN, M. H. A., PERVIN, R. and HAQUE, M. R. 2015. Study

on the socio-economic condition of fishermen of the Punorvaba River under Sadar upazila, Dinajpur. Journal of Fisheries 3(1): 239-244. DOI: dx.doi.org/10.17017/jfish.v3i1.2015.50

NAYEem, M. A., PERVIN, K., REZA, M. S., KHAN, M. N. A., ISLAM, M. N. and KAMAL, M. 2010. Marketing system of traditional, dried and semi-fermented fish product (Chepashutki) and socioeconomic condition of the retailers in local markets of Mymensingh region, Bangladesh. Bangladesh Res. Pub. J. 4(1): 69-75.

QUDDUS, M. M. A. and SHAFI, M. 1995. Bongoposhagorer Motsya Sompod. Bangla Academy, Dhaka. Bangladesh. 426pp.

RAHMAN, A. K. A. 2005. Freshwater Fishes of Bangladesh. Second ed. Zoological Society of Bangladesh, Dhaka, Bangladesh. 394pp.

SHAMSUDDOHA, M. 2007. Supply and value chain analysis in the marketing of marine dried fish in Bangladesh and Non-Tariff Measures (NTMs) in international trading. Proceedings of the EAAE Pro-Poor Development in Low Income Countries: Food, Agriculture, Trade and Environment, October 25-27, 2007, Montpellier, France.

SHARIF, B. M. N., AL-ASIF, A., VAUMIK, S., ZAFAR, M. A., ISLAM, M. M. and SAMAD, M. A. 2015. Socioeconomic condition of fish farmer and trader at the village of Pitamborpur in Chaugachha upazilla in Jessore, Bangladesh. International Journal of Fisheries and Aquatic Studies 3(2): 212-217.

SUlTANA, P. and THOMPSON, P. M. 2007. Community based Fisheries Management and fisher livelihoods: Bangladesh Case Studies. Hum. Ecol. 35: 527-546.

TALWAR, P. K. and JHINGRAN, A. G. 2001. Inland Fishes.Vol.2. Oxford IBH Publishing Co. Pvt. Ltd, New Delhi, Calcutta. 1158pp.

ZAMAN, T., JEWEL, M. A. S. and BHUIYAN, A. S. 2006. Present status of pond fishery resources and livelihood status of the fish farmers of Mohanpur upazila in Rajshahi District. University Journal of Zoology, Rajshahi Universiy 25:31-35.

(Manuscript received on 7 October 2020 revised on 14 June, 2021) 